\title{
Child Character Building through the Takaplager Village Children Forum
}

\author{
Ludovikus Bomans Wadu*, Robeka Novita Dua \\ Kasing, Andri Fransiskus Gultom \\ Universitas PGRI Kanjuruhan Malang \\ Malang, Indonesia \\ *ludovikusbomanwadu@unikama.ac.id, \\ opekasing@gmail.com, andri.franz@unikama.ac.id
}

\author{
Klemens Mere \\ Universitas Katolik Widya Karya \\ Malang, Indonesia \\ klemensmere@widyakarya.ac.id
}

\begin{abstract}
This study aims to determine the process of character value formation through non-formal education with the Takaplager Village Children Forum in Sikka Regency, East Nusa Tenggara, Indonesia. This research uses a qualitative approach with a case study approach. Data were collected using: triangulation techniques, observation, interviews, and documentation. The research subjects were micro and macro levels. At a micro, one or two individuals have an idea about the daily situation of children in Takaplager. Researchers, at the macro level, directly with the community in this case Wahana Visi Indonesia (WVI) and community members in Takaplager village. The results of this study indicate that: firstly, village children forums can shape children's character through two pedagogical processes that are experience and training. Experience through the formation of religious, creative, and independent values. The formation of character values through a training process of activities of reading, making friends with direct communication, caring socially, hard work and loving the country. Secondly, character values form habituation that shows a real effort to practice the values in life. The conclusion of this research were building children's character need support and cooperation from family, school, and community.
\end{abstract}

Keywords-character, mental revolution, civic education, habituation

\section{INTRODUCTION}

This article discusses the formation of children's character as an effort to mental revolution through non-formal education, namely the Takaplager village children's forum. The definition of child in this study refers to the UNICEF definition: all people under 18 years of age, unless otherwise specified by the laws of a country. In the constitution of Indonesia, with reference to Law no. 35 of 2014 concerning Child Protection, article 1 , a child is someone who is not yet 18 years old, including children who are still in the womb who have rights such as the right to live, grow, develop, and participate optimally in accordance with human dignity, and receive protection from violence and discrimination.
Children become the nation's next generation with great responsibility and morals. However, de facto, Indonesia is experiencing a moral decline which has become rampant due to globalization [1]. Globalization currents that can erode children's personalities such as having an instant mentality, being dishonest, reactive, irresponsible, and having a violent mentality [2]. The variant of this tendency indicates that there is a need for habituation in education, both formal and nonformal. Habituation, with the aim of forming a character with a personality, is not just providing knowledge about instilling good and bad things but being able to implement it sustainably [3].

Initial efforts to shape character have been initiated by the Indonesian government through a mental revolution. Mental revolution is defined as a movement of comprehensive changes in life, which means efforts to shape the character of young generation in order to revolutionize their mentality to change habits from all aspects of life so that changes occur to fix their mentality both in behavior and actions [4]

Normative character education when aimed at children is carried out to improve the character, personality, mindset, behavior, character in accordance with moral norms and principles in society and can shape national identity [5]. There are three education centers as a means of shaping children's character: family, school and community [6]. Character building is carried out in order to improve the nature, personality, mindset, behavior, character in accordance with the norms and moral principles in society which cannot be separated from the support and cooperation of the three children's education centers: the family, school and community environment [7]. Mental Revolution is as important as character education in shaping the mental or character of the nation's children related to knowledge, attitudes and human behavior that are good and in accordance with norms [8]. This aims to encourage and prepare the younger generation to grow into children with good and right personalities and to be able to practice them in community and nation life [9]. 
One of the processes of preparing children's character is through civic education [10]. Citizenship education can equip students with character, basic knowledge regarding the relationship between citizens and the nation with the aim that the next generation can be relied on by the nation [11]. The culture of the Indonesia is expected to be manifested in the form of behavior in daily life as individuals and members of society and creatures of the Almighty God.

There are several studies that have examined the character building of children. Regarding the formation of children's character through family, school and community [12]. Examines the character building of children with a sports spirit through physical education, sports and health [13]. Regarding schools collaborating with parents in shaping the character of students and schools implementing this strategy to strengthen student character [14].

Several studies that have been conducted focus more on the process of forming children's character through formal education. The focus of research on this text is to examine more about the formation of children's character as an effort of mental revolution through a non-formal education in the form of a village children forum. In previous studies, the scope studied by previous researchers only focused on one-character value or character in general, while in this paper the scope of this study examines the overall character values that can be formed in the village children forum. Following the previous research, the parties involved were only teachers, students, parents only, while in the research, the researchers involved children, parents, Village Children Forum administrators and community leaders.

\section{MethoDS}

This research uses a qualitative approach with the type of case study research. Data collection procedures in this study were carried out through observation, interviews and documentation. Data analysis techniques used reduction, display and data verification. Triangulation technique is a technique used to check the validity of data from the data sources obtained.

The research design is devoted to observing the characters of Takaplager children who undergo changes towards a more civic disposition character. The researchers began the research phase by looking at the gap that occurred in Takaplager village as the lol of the study. The second step, the researchers conducted a document study that looked for previous researches that had examined the character situation in Takaplager. The third step, the researchers then approached by looking for informants, namely some members of Wahana Visi Indonesia (WVI), traditional leaders, some parents and mobilizers in the field of literacy. These are people who are struggling to improve the quality of education. The fourth step, the researchers lived together (live in) with the children, observed the habits they did in their daily activities, and then recorded them in a field note. The fifth step, the researchers verified data with triangulation technique through custom leaders, experts, and recording them in the data card. The last step, the researchers made a research report

\section{RESULTS AND DISCUSSION}

\section{A. Character and Mental Revolution}

Character are the values of human behavior related to God Almighty, oneself, fellow human beings, the environment and the nation which are manifested in thoughts, attitudes, feelings, words, and actions based on applicable norms. There are eighteen character values identified from the four sources of character education: (1) religious; (2) honest; (3) tolerant; (4) discipline; (5) hard work; (6) creative; (7) independent; (8) democratic; (9) curious; (10) spirit of nationality; (11) love the country; (12) rewarding achievement; (13) friendly / communicative; (14) peace-loving; (15) likes to read; (16) cares for the environment; (17) social care; (18) responsible [15].

Character building in children should be done from an early age, because in fact character building does not take place quickly but must go through a process that can educate and perfect the morals of the next generation towards a better direction. Character becomes a strong foundation in shaping humans in their behavior by changing negative things to be positive in their daily lives which will become good habits.

The formation of children's character through education is imperative to make students smart, have good manners, and other good values so that they become members of society who can be useful for themselves and others. Character education can develop character values that must be instilled in children so that they can apply these good values in everyday life. The values developed by character education in Indonesia come from 4 sources: religion, Pancasila, culture and the Goals of National Education.

Indonesian society is a religious society, therefore all life, deeds, humans are always based on religious teachings. Second, Pancasila is the basis of the Unitary State of the Republic of Indonesia, the values contained in Pancasila are the basic values that govern the life of the nation and state. Third, culture as a truth that human live in a society based on cultural values recognized by society. Culture gives meaning to a concept in communication between members of the community itself. Fourth, the purpose of National Education, as a quality formula that every citizen must have, is developed through various education units, the objectives of education contain various human values possessed by citizens [16].

The mental and character revolution is a mutually consistent unit in a process based on the desire to change individual habits so that there is a fundamental change in organizing the mentality of behaving and acting in everyday life [17]. Mental revolution is very much needed in changing human to be an even better person. This changing of old habits into new habits is to make the Indonesia a country with character. Mental revolution is also an educational process in terms of shaping and developing character to strengthen the 
mentality of the nation's next generation. To improve the morale and character of the nation's children so that it is in line with the hopes and aspirations of Indonesia as a nation, it is necessary to establish an education system regarding a mental revolution that can be felt by all future generations of the nation.

Mental revolution is an effort to shape character because it is sustainable. Humans who have character and always instill the values of goodness that will always love God and others, responsibility, discipline, independence, honesty, respect, and other human values are the practice of mental revolution. Mental revolution needs to be implemented to eradicate all kinds of mentality that destroy character, such as emotions, mentality, soul, mindset, behavior, actions that are negative and can damage the nation's morals. Indonesian society is experiencing a character crisis that can kill the national identity, therefore character education and mental revolution in the younger generation must be emphasized, one of which is through education so that they become cultured and valueoriented human beings and implement the characters in real life [18].

\section{B. Non-Formal Habituation}

Habituation is a term that comes from the word "habit", then habituation is understood as a process of habituation. Habituation when referring to historical traces of thought. Habituation, for Aristotle, is very close to virtue ethics for moral education [19]. Habituation is a term often understood to derive virtuous character through repeated practice of virtuous acts.

In Nicomachean Ethics (NE), Aristotle suggests habituation as a lifelong process. Humans, wrote Aristotle (1934), must confirm their habits when they are adults (NE. 1080a). The habituation or habit referred to by Aristotle implies that it is aimed at young humans. Habituation in the literature that refers to Aristotelian thought can be used in children as a method of moral education. Habituation for children, because there is an offer from Aristotle's thought about habituation which is then reconstructed by Sanderse by further describing what is in the Nicomachean Ethics.

Aristotle stated that full virtue is impossible without practical wisdom. That is, he argues that society can make moral progress through habituation and education (through the teaching process). Right at the start of II Nicomachean Ethics, Aristotle distinguishes between moral and intellectual virtues and argues that intellectual virtue is stimulated through instruction, while moral virtue is a product of habituation (NE.1103a15-20). Here, Aristotle provides an explanation that the process of habituation of a virtuous person also needs to develop practical skills. For example, a builder will have skills if he is able to build a house. That is, in the process of habituation, there is a process of change, namely from potential to actual. The process of change only exists and occurs in action (NE,1103a32-b2). Thus, the basic idea of habituation is that virtue is formed as a result of action (actus).
Habituation is more focused on what is referred to as "the conditioned character", a conditioning to direct humans to virtuous actions [20]. Those conditioning is not sufficient in formal situations, for it requires practical virtue. These practical virtues can be found in the non-formal education route.

\section{Character in Non-Formal Education}

The character-building process in this study leads to the non-formal education path, namely through the Village Children Forum. The Village Children Forum is placed in the locus of children in Takaplager village, Nita District, Sikka Regency, East Nusa Tenggara, Indonesia. The Village Children Forum is an out-of-school educational forum that aims to shape children's character as an effort for mental revolution. Village children forum, thus, is a form of out-of-school education that is important for improving the quality of life that is better than that obtained in the scope of formal education.

Takaplager Village is one of the villages selected by a nongovernmental organization called Wahana Visi Indonesia to run the Village Children Forum program. Wahana Visi Indonesia (WVI) is a Christian humanitarian social foundation based on Pancasila as the only principle in the life of society, nation and state. WVI carries the goal of improving the welfare of children, families and communities through development efforts in the fields of education and advocacy programs, health, economic empowerment, participation and child protection.

Sikka's WVI Area Program (AP) works in three subdistricts, namely Nita, Lela, and Doreng Districts, with 20 service villages, one of which is Takaplager village. Replication of character education is carried out in two ways, namely increasing the capacity of teachers through teacher training and increasing children's capacity through activities outside of children's schools. In this study, the focus is on children's outside school activities with the aim of supporting children's life skills through the Village Children Forum.

The main task of the Village Children Forum is to become a means for children in the village to participate in development and has functions, namely (1) monitoring the fulfillment of children's rights and the implementation of obligations; (2) socialization of children's rights and obligations among peers; (3) voicing the views and aspirations of children in Takaplager village; (4) involve themselves in the decision-making process and encourage the active children of the Village Children Forum to develop their potential and interests and talents.

\section{Character and Habituation in the Takaplager Village Children Forum}

Based on the results of observations, interviews, and documentation, it is found that character values can be formed through various activities of the Village Children Forum. The Village Children Forum is able to form the eighteen-character values mentioned [4]. However, the researchers found that 
there were eight-character values whose formation was more dominant, and the teaching process and its habits could be directly observed. The eight dominant character values in the Village Children Forum are: (1) religious character values; (2) creative; (3) independent; (4) likes to read; (5) friendly / communicative; (6) social care; (7) hard work; (8) love the country.

From the results of the research, these character values are formed through forum activities and those prepared by village children forum assistants to shape children's character. The value of religious character can be seen from the activities of children who are active in the church such as being a son/daughter of the altar who helps smooth the process of worship in the church, creative value is formed through the activity of recycling used goods into items that are fit for use and have selling value. Independent, it can be seen from the children who have dared to do something without any help from other people in participating in the competition and there are some toddlers are able not to be depended on their parents.

Observation on the fourth value, namely reading fondness, is manifested in reading activities in Foranta's reading garden named Bida Mitan. The results of the observation on the fifth value are friendly/communicative, marked by the activity of familiarizing the children in intimate meetings between districts. Observation on the sixth value, namely social care, is seen when the children are accustomed to visiting the orphanage beach and providing assistance to the orphanage. Observation on the seventh value, namely hard work, shows that the children in the Village Children Forum are seen when they are responsible by actively participating in carrying out each given task. The eighth value, namely love for the country, is seen when the children practice dancing and playing traditional musical instruments, which indicates that they love culture.

Based on the findings in the field, character values that can be formed through village children forums as an effort of mental revolution are classified into two-character building processes: pedagogy and training. Pedagogy is a method used in educating children /students by means of good and wise delivery so that they are easy to understand and involve the experience of their personal situations so that will be always remembered [21]. Character values that can be formed through the village children forum are classified into pedagogical values: religious character values, creative and independent values, these character values can be seen from activities that have been carried out so far such as sharing activities in the church, children's creativity in recycling goods, and children become independent children and are not easily dependent on others. These three-character values are classified into the process of forming a pedagogical or experiential character because they are formed based on a situation that is directly experienced which in turn becomes a continuous knowledge that will become a habit for children in the Village Children's Forum.
Training is a task or effort to increase knowledge and improve skill mastery routinely in every activity that has a clear direction so that the desired results are achieved [22]. The results of this research are that the character values that are categorized as training are character values like reading, friendly/communicative, social care, hard work and love for the country. These five-character values are formed through several activities that have been designed and planned by the management at the Village Children Forum. The form of activities carried out by the Village Children Forum aims to improve and develop children's attitudes and behavior in order to achieve the goals of an organization from the Village Children Forum; that is, shaping children's character.

One question that needs to be asked for deepening in the results of this research is how the habituation of characters works in the Village Children Forum? Habituation in twocharacter building processes, namely pedagogical and training. The first pedagogical habituation process in this study is represented in the habituation process of children in SEKAMI in the church. Habituation works as the conditioned character based on previous observations, children run around when church members to worship on Sundays, throw garbage inappropriately, have less interest in learning, have minimal religious knowledge, and lack communication skills. The qualitative data shows the low character of the children. The habituation process is then carried out with the first commitment from the SEKAMI teachers and parents to invite the children to gather in one room to pray and play with. The methods used in habituation are storytelling, role playing, drawing practice, and presentation of work results. The essence of habituation is that children are involved in actions to change the character from being less coordinated to become well organized.

Habituation in the training process is represented in the character values like reading. The results of the interview from a source revealed the negative situation that occurred to the child. A source revealed that, "what is even more concerning is that in his own village there are children who, seeing their parents playing billiards and gambling, end up playing billiards and gambling. Their childhood just passed by with negative things. "If you have been accustomed to billiards and gambling since childhood, what will the children in this village be when they grow up?"

This negative situation, after being verified by researchers, actually happened to some children. The researcher then observed further and found that there was a conditioning that was deliberate by a character to invite the children to the library named Bida Mitan. In the library, the children are then introduced to books, then they are accustomed to being fonder of reading rather than playing billiards and gambling. In this habituation, children's time is spent more in the library than outside time which is less coordinated. Habituation in observations was carried out with a briefing from the library owner and the provision of additional facilities to eliminate boredom such as bringing in several musical instruments, writing instruments, colored pencils, drawing books and a 
number of sports equipment. As a result, there is an increase in the number of children coming to the Bida Mitan reading garden.

\section{CONCLUSION}

Efforts to shape children's character as an effort to mentally revolutionize the need for good support and cooperation from the three education centers, namely family, school and community. Character in civic education exists in the form of formal education and non-formal education to shape citizens in three aspects: civic knowledge, civic skills, and civic disposition. These three aspects can be realized in formal education and non-formal education. This study embodies these three aspects in the Takapleger Village Children Forum with the findings that there are eight dominant character values, namely: (1) religious character values; (2) creative; (3) independent; (4) likes to read; (5) friendly/communicative; (6) social care; (7) hard work; (8) love the country. These eight are manifested through habituation in the field of pedagogy and training to shape the character of the Takaplager village children as part of an ongoing mental revolution effort.

\section{ACKNOWLEDGMENT}

This article publication in ANCOSH 2020 proceeding is supported by the Rector of University of PGRI Kanjuruhan Malang.

\section{REFERENCES}

[1] M. Iskarim, "Dekadensi Moral di Kalangan Pelajar (Revitalisasi Strategi PAI dalam Menumbuhkan Moralitas Generasi Bangsa)," Edukasia Islam. J. Pendidik. Islam, vol. 1, no. 1, pp. 1-20, 2016.

[2] A. F. Gultom, M. Munir, and I. Ariani, "Perubahan Identitas Diri Dalam Eksistensialisme Kierkegaard: Relevansinya Bagi Mental Warga Negara Indonesia," J. Pendidik. Kewarganegaraan, vol. 9, no. 2, pp. 77-84, 2019.

[3] Y. Mujiwati, "Peranan Pendidikan Karakter Dalam Pembangunan Karakter Bangsa,” J. Ilm. Edukasi Sos., vol. 8, no. 2, pp. 165-170, 2018.

[4] H. Suwardana, "Revolusi Industri 4. 0 Berbasis Revolusi Mental," JATI UNIK J. Ilm. Tek. Dan Manaj. Ind., vol. 1, no. 2, pp. 109-118, 2018.

[5] D. Suhardi, "Peran SMP berbasis pesantren sebagai upaya penanaman pendidikan karakter kepada generasi bangsa," J. Pendidik. Karakter, no. 3,2012 .
[6] M.I. Kurniawan, "Tri pusat pendidikan sebagai sarana pendidikan karakter anak sekolah dasar," Pedagog. J. Pendidik., vol. 4, no. 1, pp. $41-49,2015$.

[7] C. Mei-Ju, Y. Chen-Hsin, and H. Pin-Chen, "The beauty of character education on preschool children's parent-child relationship," ProcediaSocial Behav. Sci., vol. 143, pp. 527-533, 2014.

[8] N. W. Wardhani and N. Noorrochmat, "Revolusi mental dalam cerita Babad Alas Wanamarta," J. Civ. Media Kaji. Kewarganegaraan, vol. 13, no. 2, pp. 182-187, 2016.

[9] M. Leasa and J. R. Batlolona, "Full day school dalam pembentukan karakter siswa SMKN 13 kota Malang," J. Ilmu Sos. dan Hum., vol. 6, no. 1, pp. 73-82, 2017.

[10] P. Dianti, "Integrasi Pendidikan Karakter dalam pembelajaran Pendidikan Kewarganegaraan untuk mengembangkan karakter siswa," J. Pendidik. Ilmu Sos., vol. 23, no. 1, 2014.

[11] A. Suharyanto, "Peranan pendidikan kewarganegaraan dalam membina sikap toleransi antar siswa," JPPUMA J. Ilmu Pemerintah. dan Sos. Polit. UMA (Journal Gov. Polit. Soc. UMA), vol. 1, no. 2, p. 12, 2013.

[12] D. Prasanti and D. R. Fitriani, "Pembentukan karakter anak usia dini Keluarga, sekolah, dan komunitas?(Studi kualitatif tentang pembentukan karakter anak usia dini melalui keluarga, sekolah, dan komunitas)," J. Obs. J. Pendidik. Anak Usia Dini, vol. 2, no. 1, pp. 13-19, 2018.

[13] D. Yuliawan, "Pembentukan karakter anak dengan jiwa sportif melalui pendidikan jasmani olahraga dan kesehatan,” J. Sport., vol. 2, no. 1, pp. $101-112,2016$

[14] Y. Wulandari and M. Kristiawan, "Strategi sekolah dalam penguatan pendidikan karakter bagi siswa dengan memaksimalkan peran orang tua,” JMKSP (Jurnal Manajemen, Kepemimpinan, dan Supervisi Pendidikan), vol. 2, no. 2, pp. 290-302, 2017.

[15] A. Ghufron, "Integrasi nilai-nilai karakter bangsa pada kegiatan pembelajaran," J. Cakrawala Pendidik., vol. 1, no. 3, 2010.

[16] A. Dahliyana, "Penguatan pendidikan karakter melalui kegiatan ekstrakurikuler di sekolah," Sosio Reli. J. Kaji. Pendidik. Umum, vol. 15 , no. 1,2017

[17] A. F. Muhlizi, "Revolusi Mental Untuk Membentuk Budaya Hukum Anti Korupsi," J. Rechts Vinding Media Pembin. Huk. Nas., vol. 3, no. 3, pp. 453-472, 2014

[18] F. Sanjaya, "Analisis Wacana Kritis Berita Penerapan Revolusi Mental," Oratio Directa, vol. 1, no. 2, 2018

[19] W. Sanderse, "Does Aristotle believe that habituation is only for children?," J. Moral Educ., vol. 49, no. 1, pp. 98-110, 2020.

[20] N. Bowditch, "Aristotle on habituation," 2008

[21] N.M.C.K. Dewi, I.N. Sudiana, and G. Artawan, "Penerapan Model Pembelajaran Melalui Pengalaman Berbantuan Media Grafis Untuk Meningkatkan Kemampuan Menulis Puisi Siswa Kelas VIII. A SMP Dharma Wiweka Denpasar,” J. Pendidik. Bhs. Dan Sastra Indones. Undiksha, vol. 2, no. 1, 2014.

[22] V. N. Turere, "Pengaruh pendidikan dan pelatihan terhadap peningkatan kinerja karyawan pada Balai Pelatihan Teknis Pertanian Kalasey," J. EMBA J. Ris. Ekon. Manajemen, Bisnis dan Akunt., vol. 1, no. 3, 2013. 